\title{
Xanthine Oxidase Inhibitor
}

National Cancer Institute

\section{Source}

National Cancer Institute. Xanthine Oxidase Inhibitor. NCI Thesaurus. Code C1637.

Any substance that inhibits xanthine oxidase, an enzyme that catalyzes the oxidation of hypoxanthine to xanthine and xanthine to uric acid, along with the generation of reactive oxygen species (ROS). Inhibition of xanthine oxidase can reduce the production of uric acid. 